\title{
Competition Policy in the World Trade Organisation
}

\author{
David Robertson
}

T

THE diminishing significance of most industrial tariffs for OECD countries as the Uruguay Round reductions are implemented has drawn attention to the protection and discrimination that can arise from differences between domestic policies. This issue has prompted proposals to include competition policy on the agenda for the WTO's first ministerial meeting, to be held in Singapore in December 1996 (Feketekuty, 1992). The Uruguay Round agreement on traderelated investment measures (TRIMs) requires a review within five years that should include consideration of 'provisions on investment policy and competition policy' (Article 9). Some governments would like to initiate work on this review sooner rather than later. Several trade disputes have occurred recently over restrictive business practices affecting access to markets, such as the US-Japan confrontation over access for automobile parts which was settled in June 1995.

Successive rounds of multilateral trade negotiations in the GATT have progressively expanded their scope to address domestic policies affecting trade. At the same time, advances in technology (especially in telecommunications and transport) combined with political and social changes have reduced economic distances and led to the globalisation of production and marketing decisions. Global businesses' concerns about market access and competitiveness for trade and investment coincided with official acceptance that trade-related domestic policies should be governed by international rules and disciplines. The attempts to establish codes on product standards, subsidies and government procurement in the Tokyo Round (1979) were elaborated in the Uruguay Round, and new agreements were added to cover intellectual property rights (TRIPs), TRIMs, quarantine standards and trade in services (GATS). These measures and some strengthening of trade rules in the Uruguay Round bear directly on competition policies.

The goal of competition policy is to maximise technical efficiency and to optimise economic welfare by promoting competition among suppliers of goods and services. Trade and investment policies and domestic competition policy should be complementary. But the benign effects of dismantling border barriers to trade and investment can be nullified by domestic policies that discriminate against foreign producers. Allowing cartels or exclusive dealing with distributors or suppliers, whether through inadequate competition laws or poor enforcement, can stifle do-

David Robertson is Director of the Trade and Development Program at the National Centre for Development Studies, The Australian National University. 
mestic competition and may discriminate against foreign suppliers. Trade disputes may be avoided by making national competition policies subject to some international coordination or supervision. Provisions already exist in GATT (1994) ${ }^{1}$ articles that could be adapted to meet these new sources of trade friction. But negotiations on competition policy in the WTO seem likely to be long and complicated.

\section{What Is Competition Policy?}

Competition (or anti-trust) policy refers to the removal or control of government measures and private restrictive practices that prevent the efficient functioning of a market. Many economic theorems are founded on the concept of 'perfect competition', meaning that large numbers of buyers and sellers operate to determine a market price. The aim of competition policy is to remove - or at least prevent increases in - barriers to entry or exit in specific domestic markets, so creating scope for potential new entrants (national or foreign) to constrain the behaviour of existing producers. Competition facilitates efficient resource allocation, raises productivity and prevents profits from increasing at the expense of higher prices to consumers.

Competition rules may be applied through legal systems or by administrative processes. In the United States, anti-trust is enforced through criminal prosecutions in the courts initiated by the Federal Trade Commission, with severe penalties applied, including treble-damage suits and imprisonment. Private anti-trust damages may likewise be pursued through the courts. In the European Union (EU), competition policy plays a key role in the unified market. In keeping with practices in member countries, competition rules are enforced by administrative orders. The European Commission initiates, investigates and issues orders to discontinue certain practices, and imposes fines. Its decisions may be reviewed by the European Court of Justice. In Japan, competition rules, modelled on the US laws, were enforced through the courts. But in 1977 supplementary administrative fines were also introduced. This hybrid system has become a source of controversy between the US and Japanese authorities.

In Australia, the Australian Competition and Consumer Commission (ACCC) began operations in 1995 to administer the Trade Practices Act and the Prices Surveillance Act. The ACCC has powers to deal with competition and efficiency in markets, fair trading, competitive pricing, merger proposals, monitoring of prices, cost and profits, and so on. Substantial fines may be levied on transgressors.

In practice, competition in a market is influenced by many domestic rules and regulations, such as product standards, environmental requirements, intellectual property rights, corporate law, legal standards, and the like. Industry policy and social welfare programs also affect the application of domestic competition policies; economies of scale may depend on limiting the number of domestic firms in an

\footnotetext{
1 GATT (1994) comprises the original GATT (1947) as amended by Uruguay Round agreement and new rules affecting merchandise trade. It forms one leg of the WTO, the others being GATS, TRIPs and the undertaking on dispute settlement procedures.
} 
industry to establish competitively priced exports, or regional unemployment may create political pressures to keep plants open even though they are uneconomic or uncompetitive.

Applying competition rules, therefore, requires major trade-offs among social objectives. Political considerations come into play. Some firms stand to gain by restricting entry to a market, and anti-competitive practices (collusion or exclusive dealing) may achieve this as effectively as import barriers. Government policies of all kinds are important incentives for 'rent-seeking' (Baldwin, 1989). Just as an import tariff, by raising product prices, transfers income towards domestic producers of the protected good, so domestic lobbying to restrict entry to an industry transfers income towards the monopolistic firm. Political institutions and government structures determine the way lobbying works, and political forces help to frame competition laws and their application.

Assessing national competition laws and their administration is difficult because over time attitudes towards market competition change. Different private business practices, and different aspects of competition receive attention. Four types of anticompetitive private behaviour are usually identified:

- cartels and other horizontal price-fixing arrangements;

- dominant market positions (merger policies);

- vertical restraints, linking production with sourcing or distribution networks; and

- special cooperation in transborder transactions by multinational enterprises.

Government measures may also promote anti-competitive behaviour. So-called 'natural' monopolies (public utilities) have long received national protection, and only now are giving way to privatisation. These industries provide the battleground for the continuing GATS negotiations concerning, for example, telecommunications and maritime transport. Access to those service markets has become a source of serious trade disputes between the US and Japanese and EU authorities; recently these disputes have spread to include several dynamic Asian economies.

Maintaining domestic competition should also allow for foreign competition. Imports set a valuable standard against which domestic production should be judged, while ability to export is a good sign that domestic markets are effective. National competition policies are often applied only to domestic producers, while import competition is regulated by trade policy instruments. Contingent protection, ${ }^{2}$ especially anti-dumping action, is a convenient method of insulating domestic

\footnotetext{
${ }^{2}$ Contingent protection as provided in the GATT since 1947 continues in GATT (1994). Emergency protection may be introduced where injury to domestic import-competing industries is caused by 'unfair' competition ('dumped' or subsidised exports) or by imports causing 'market disruption', when temporary import restraints are permitted.
} 
markets from foreign competition. The strengthening of rules on subsidies and safeguards in the Uruguay Round should make these GATT escape clauses less accessible. Yet anti-dumping remains as an exception to genuine competition. Until OECD countries indicate willingness to relinquish anti-dumping policies, they will find it difficult to convince the dynamic economies of Asia and Latin America that they are serious about competition policy.

In Australia, for example, allegations of dumping (whereby imports are sold at lower prices than in their home markets) are dealt with by the Anti-dumping Authority (ADA), which applies different criteria from the Australian Competition and Consumer Commission. In practice, anti-dumping actions are based on dubious measurements and tend to eliminate foreign competition from domestic markets. Moreover, the interests of consumers and user industries are ignored in favour of import competing industries' complaints. Price discrimination between separated markets is not in itself harmful to economic welfare; it can represent profit maximising behaviour. Yet 'selling below normal value' is about price discrimination. At least anti-dumping actions should be subject to challenge according to domestic competition policies.

\section{Exceptions to Competition Rules}

Even as proposals to establish international rules of competition are being made, some domestic industries are arguing for protection of home markets in the national interest. In the US, calls for 'strategic' trade protection continue even while the US authorities are exerting pressure on the Japanese government to reduce restrictive business practices affecting telecommunications, microchips and motor vehicles (keiretsu ${ }^{3}$ and exclusive dealing). Some domestic US industries argue that a certain 'critical mass' market is necessary to achieve economies of scale (especially with regard to research and development) that permit domestic firms to compete in world markets (Tyson, 1992). Fortunately, liberalisation of trade and investment policies has resulted in most businesses focusing on the global market for economies of scale. Even so, disputes over domestic competition policies and their enforcement will continue, which makes WTO negotiations on this issue important.

Traditionally, cartels have been regarded as anti-competitive and against the interests of consumers. Yet even countries with strong anti-trust laws, such as the US and the EU, exempt certain collusive activities. For example, export cartels, agricultural marketing boards, cooperation agreements on research and development, insurance-rate setting and labour union collective bargaining seem to be regarded as politically acceptable. In addition, governments accept 'crisis cartels' for declining industries where excess capacity has to be retrenched, especially during economic recessions (for example, EU synthetic fibres, shipbuilding and steel).

${ }^{3}$ Keiretsu are business groupings, often spreading across several industries, which manage trade among the constituent companies (vertical and horizontal) in ways that discriminate against imports and do not allow foreign participation. Keiretsu may be vertically or horizontally integrated or they can be conglomerates. 
Often these cartels have been supported with trade measures, such as voluntary export restraints (VERs) or anti-dumping duties. It is evident that, even in the case of cartels, the welfare benefits from competition rules are often sacrificed to political expediency. With so many exemptions from anti-trust legislation, achieving a set of international principles for competition policy will not be easy. Such government discretion highlights hidden discrimination through regulatory competition among governments.

There are three stages of competition policy that may affect market access. First, differences between domestic rules of competition affect trade and investment decisions. Second, the enforcement of existing policies may be varied to meet specific interests. Third, governments may design rules and regulations to achieve political objectives, resulting in competition between national policies.

The WTO, like GATT, is empowered only to deal with government policies. Hence, any principles agreed on competition policy would apply to competition rules and their enforcement, but it could not apply to the use of specific restrictive business practices by private enterprises. In present circumstances, a private restrictive practice can be tackled only by calling on a government to take action. GATT rules cannot be applied against an offending firm. With production and marketing undertaken on a global scale, the scope of business activities makes action by one government problematical. It could simply cause an enterprise to shift its operations to another country with more amenable rules or administration.

\section{Extra-Territorial Actions}

In the absence of principles of international competitive behaviour, some governments have attempted to apply their domestic legislation extra-territorially. Where anti-competitive practices abroad affect prices or access to their domestic markets, such actions by large countries carry some threat. Collecting evidence of unfair competition in another country is difficult, however, because commercial information is confidential and often legally protected. In some instances, target companies have obtained legal protection from blocking legislation that prohibited them from supplying information sought by foreign courts. Australian uranium exporters were granted this blocking legislation when Westinghouse brought an anti-trust case for alleged price fixing late in the 1970s. Canada, France and Britain have used similar legislation to counter US court demands.

Since in an interdependent global economy the nationality of a company or product is increasingly difficult to establish, matters of cross-frontier competition become international rather than national issues. Multinational enterprises can engage in anti-competitive practices and avoid national jurisdictions. If such behaviour takes place in a country that does not have competition rules, another country can attempt only extra-territorial application of its legislation. Vertically integrated multinational enterprises can locate production in a country without competition rules, just as they can avoid national environment or production standards or labourunion restrictive practices. Transfer pricing may aggravate the damage from such investment shunting. Transfer pricing as practised by some multinational enter- 
prises in the 1970s put all multinationals in bad odour. Combating such damage can be attempted only by using extra-territorial applications, unless intergovernment cooperation in competition law enforcement is achieved.

The OECD has been trying for over 20 years to deal with some of these interjurisdictional problems by fostering cooperation among competition law enforcement agencies. Guidelines were drawn up for notification, information exchange, consultation and conciliation. One objective of these guidelines was to promote convergence of competition policies, but cooperation is limited by differences in national laws and procedures. The OECD claims that sharing information between enforcement agencies and mutual assistance in investigations has increased (Phillips, 1995). Bilateral agreements have also been concluded. In 1991 an agreement between the US government and the EC Commission regarding the application of competition laws ${ }^{4}$ introduced the concept of 'positive comity' which provides that a government affected by an anti-competitive business practice taking place in another's jurisdiction can call on the latter to take enforcement action under its own laws. This goes beyond conciliation and cooperation, but a country is not obliged to accede to a request if public policy objectives do not coincide in the two countries.

Harmonisation of competition policy has gone further in some regional trade agreements. Because the EU has a common external trade policy and a unified internal market, competition policy is crucial to maintain free movement of goods, services and capital, and provides freedom of establishment throughout the EU. The North Atlantic Free Trade Agreement (NAFTA) acknowledges the links between trade, investment and competition policy, but its provisions preserve rights of member countries to use trade remedies (anti-dumping and countervailing duties, and other trade safeguards). Intergovernmental cooperation is left to deal with any trade frictions caused by anti-competitive behaviour, which represents little advance over the OECD approach. The Australia-New Zealand Closer Economic Relations Agreement contains a separate protocol for full cooperation in enforcement of competition policy by harmonising rules governing abuse of market dominance and abolishing anti-dumping actions between the two countries. Any pricing dispute has to be dealt with under national competition laws (Lloyd, 1995). No case has arisen since 1990.

In APEC, the Eminent Persons Committee has called for a dispute settlement process to be established to deal with differences over competition policy and for a study group to examine differences in competition policy among APEC economies. Ministers accepted the need for collective action on competition policy in the Osaka agenda agreed in November 1995. This is likely to lead to a study group report to the Committee on Trade and Investment. Average industrial tariffs in many East Asian economies remain high, however, and form a more significant barrier to market access than differences in these countries' rudimentary competi-

\footnotetext{
${ }^{4}$ Antitrust and Trade Regulation Report, September 1991:382-5. See Scherer (1994).
} 
tion policies. US-Japan disputes over competition policy remain potentially dangerous tensions in APEC trade relations.

Where 'deep' economic integration exists, harmonisation of competition policies may be sufficient to eliminate trade frictions. But NAFTA showed that some participants even in regional trade agreements are reluctant to relinquish sovereignty over domestic competition policy. Harmonisation does not seem relevant to discussion in the WTO, whose members show wide economic disparities and political differences.

\section{The Way Forward}

Globalisation of marketing and production requires effective competition rules to reinforce the market opening achieved by liberalisation of trade and investment policies. There are three possible approaches. First, multilateral rules could be drawn up to which countries subscribe and are bound to apply these rules in their national systems. The GATT/WTO is one forum that could negotiate such rules.

Second, increasing economic interdependence could be supported by improving coordination and cooperation among national authorities. Bilateral treaties already coordinate policies and laws on taxation and criminal law enforcement, and on supervision of securities markets.

Third, a world anti-trust code could be drawn up: the ultimate step in harmonisation (Scherer, 1995). This proposal calls for an International Competition Policy Office (ICPO) to investigate complaints, enforce decisions, register cartels and collect information about their activities. Initially, its territory could be restricted to transfrontier cartels and anti-competitive practices. Any decisions could only be enforced by national authorities.

The three approaches are examined in turn.

The WTO approach. The main proposal under consideration at present is the drafting of global rules in the WTO to cover disputes arising from differences between domestic competition laws. The Uruguay Round strengthened the disputesettlement procedures which are available to arbitrate in disputes over competition policies where anti-competitive behaviour is a result of government policies or their enforcement. Already the WTO has provisions to deal with investment disputes, using GATT (1994), GATS, TRIMs and the dispute settlement procedures.

GATT Article III (on national treatment) requires governments to treat domestic and imported goods equally, subject to border charges. If this article could be amended to apply in cases where private anti-competitive behaviour denies market access, one large gap would be closed. GATT Article XXIII (on nullification and impairment) makes provision for dispute settlement where 'reasonable expectations' from the agreement are not met. This principle of non-violation could be adapted to allow sanctions against a country that refused to investigate and report on a grievance from non-enforcement of competition policy (Hockman \& Mavroidis, 1994). The WTO dispute-settlement procedures would allow an expert panel to 
adjudicate on such a complaint. If successful, the complainant could apply sanctions commensurate with the losses suffered.

The Uruguay Round agreements on subsidies and trade safeguards take steps to remove some government measures that impede competition. The GATS contains specific commitments on national treatment and commercial presence for investments in listed service industries. These GATS provisions go much further than GATT (1994) does for goods' producers. The plurilateral agreement on government procurement also increases scope for import competition in the public sector. The effectiveness of most of these Uruguay Round agreements remains to be tested.

With national competition policies subject to exemptions and differential treatment of favoured domestic producers, any set of rules attached to the WTO system faces enforcement problems. Use of sanctions may hurt a complainant as much as an offender; and, if retaliation occurs, the rules-based system of multilateral trade could be threatened. As well, the uncertain status of WTO agreements in international law makes enforcement controversial. National sovereignty is alive and healthy in national judicial systems and many are reluctant to apply the provisions of international agreements (Palmeter, 1992). This has major consequences for rules of competition and dispute settlements reached using international procedures. As many governments are answerable to their national courts for their decisions, the enforcement of the letter of a ratified international treaty is not certain. Few national courts will submit their judgements to international scrutiny, which in any case involves long delays.

Most work on international competition rules relates to countries with established competition policies, even if they are not always well applied. But many economies with vital interests in access to markets are not included in this work. One of the major advantages of using the WTO to draw up rules on competition is its comprehensive membership. One of the major consequences of the Uruguay Round was to change the map of world trade and bring in many new players. If WTO negotiations are slow, OECD agreements, such as the foreshadowed Multilateral Agreement on Investment (MAI) or a code of competition rules, could be adopted by the WTO as plurilateral agreements, which would be open to signature and adoption by WTO members but not part of the central agreement. This approach is one way of ensuring the convoy is not held back by the slowest ship. But if grafted plurilateral agreements are too comprehensive, they may be regarded as the 'Westernisation' of domestic policies by non-OECD countries. Cultural and social differences must be allowed for.

The first task of the WTO working group that is likely to be established by the forthcoming Singapore Ministerial meeting must be to define which aspects of competition policy are suitable for inclusion in new international rules. This issue of competition cuts across many types of economic transactions and activities. Moreover, many aspects of competition are already covered in WTO agreements (GATS, for example) or are under discussion in other international agencies (such 
as MAI in OECD). Defining the scope of WTO competition rules and relating them to other agreement will be a formidable task.

The cooperative approach. Because international law is so difficult to enforce and subject to so many conflicting influences, the cooperative approach to international competition rules offers advantages over a specific code of behaviour. An effective system of competition depends on national enforcement of existing law and shared principles to maintain market access against restrictive practices by public or private actions. Efforts within the OECD to increase international cooperation in anti-trust law enforcement have achieved some progress in coordinating investigations and encouraging the sharing of information among member countries.

The OECD Trade Committee is focusing its work on 'international contestability of markets'. This combines traditional concerns about trade liberalisation to increase 'market access' with freedom to invest in another country, providing 'market presence'. 'Market contestability' recognises alternative means to supply goods and services to a national market, which is the interest of global business. Market forces have brought down investment restraints and financial regulations in most countries over the past decade, and OECD Ministers are keen to establish a new set of rules for investment (MAI).

An anti-trust code. Although governments, especially trade ministers, are pressing hard for new rules on competition, the range of issues and disparities in the implementation of national competition policies indicate that negotiations will be difficult. The ideal of a new international anti-trust code, administered by an ICPO, is not likely to be realised. Sir Ieon Brittan (1992), the EU Commissioner, has acknowledged that it is not realistic to extend the principles of EU competition policy on an international scale. An agreement on rules governing cartels and private anticompetitive behaviour, he argues, would be a good start. If consensus could be reached on shared principles of market competition that minimise impediments to market access, that would be in keeping with globalisation.

\section{An Assessment}

Concerns about international competition and market access appear inconsistent with the rapid growth of international trade and investment over the past decade. Business responses to new market opportunities have been strong. Global strategies of production and marketing have been adopted by firms based in many dynamic economies, not just those from OECD countries. Business seems to be able to compete in markets and to overcome border and non-border impediments. Governments, through international agencies like the OECD and the WTO, are trying to keep up with market forces that ignore or by-pass government measures. International investment disputes are at an all-time low, yet the OECD has embarked on negotiations to establish an MAI by 1997. A similar catching-up motive seems to underlie the proposals on competition policy. 
The initiative to establish rules on competition policy comes from the US authorities, which have had a series of highly visible disputes with Japan (Drysdale, 1995) and some other countries. The US-Japan disputes have focused on keiretsu and the ineffectiveness of Japan's anti-trust legislation. Although some other disputes have arisen (with Thai and EU industries. for example), US concerns are mainly bilateral ones with Japan. Yet during the NAFTA negotiations, the US authorities did not try to establish a harmonised competition policy. At the same time, strong arguments are being made at home for the benefits of domestic cartels to strengthen export performance. Similarly, recent EU support for competition policy to be on the WTO agenda ignores the strong support for crisis cartels and strong social and industry policies among EU member governments.

The enthusiasm for including competition policy on the agenda for Singapore comes mostly from trade negotiators. Support from other ministries is not apparent. In these circumstances, the most that can be expected from the ministerial meeting will be another WTO Working Group. After all, ministers have to review the results of the Uruguay Round agreements and establish review procedures for the agenda that was built into the Final Act. Any initiative for new rules of competition must be incorporated into this review process, as a preliminary to a new round of multilateral trade negotiations to begin around the turn of the 21 st century.

\section{References}

Baldwin, R. (1989), 'The Political Economy of Trade Policy', Jounnal of Economic Literature 3(4): 119-35.

Brittan, L. (1992), European Competition Policy: Keeping the Playing Field Level, Centre for European Policy Studies, Brussels.

Drysdale, P. (1995), 'The Question of Access to the Japanese Market', Economic Recond 21: 271-83.

Feketekuty, G. (1992), The New Trade Agenda, Group of Thirty, Washington DC. (Occasional Paper No. 40).

Hoekman, B. \& P. Mavroidis (1994), 'Competition, Competition Policy and the GATT', World Economy 17: 121-50.

Krugman, P. (ed.) (1986), Strategic Trade Policy and the New International Economics, MIT Press, Cambridge, Mass.

Lloyd, P. (1995), 'The Future of Trans-Tasman Closer Economic Relations', Agenda 2(3): 267-80.

Palmeter, D. (1992), 'Environment and Trade: Who Will be Heard? What Law is Relevant?', Journal of World Trade 26(2): 35-41.

Phillips, B. (1995), 'Cooperation Among OECD Enforcement Agencies', Conference Paper, APEC Conference on Competition Policy and Law, Auckland, 24-26 July.

Scherer, F. (1995), Competition Policies for an Integrated World Economy, Brookings Institution, Washington DC.

Tyson, L. (1992), Who's Bashing Whom? Trade Conflict in High Technology Industries, Institute for International Economics, Washington DC. 